\title{
APPLICATION OF USED ENGINE OIL IN SOIL-CEMENT STABILIZATION
}

\author{
I. N. Obeta1,* and J. Ohwoganohwo² \\ 1, 2 DEPARTMENT OF CiVIL ENGINEERING UNIVERSITY OF NiGERIA, NSUKKA. NIGERIA \\ E-mail Addresses: ${ }^{1}$ obetaifeanyi@gmail.com² jefferyakpevwe@gmail.com
}

\begin{abstract}
A lot of studies has shown that the addition of oils to some soils at 3\% and $6 \%$ contaminations by dry weight resulted in an increase in the unsoaked California bearing ratio (CBR) of the soil. This paper presents the result of investigating the applicability of used engine oil at 3\% contamination as a means of reuse in the production of ordinary Portland cement (OPC) stabilized soils. The soils which are classified as clayey Gravel (GC) and clayey Sand (SC) according to the unified soil classification system were subjected to classification tests, compaction tests, soaked and unsoaked CBR tests, X-ray fluorescence and X-ray diffraction tests. The results show that there is a general reduction in the optimum moisture content of the oil contaminated soils while the effect of oil contamination on maximum dry density varied for the two types of soils under consideration. Furthermore, an increase of $130.45 \%$ and $240.37 \%$ were observed respectively in the CBR values of the oil contaminated soils after curing it for six days and soaking for 24 hours in water at $8 \%$ OPC content. The procedure for curing, soaking and CBR testing were all in line with the recommendation of the Nigerian general specification for roads and bridges.
\end{abstract}

Keywords: soil stabilization, used engine oil, soaked CBR, environmental control

\section{INTRODUCTION}

The worldwide concern for cleanup, protection and enhancement of the environment has resulted in the development of a sub discipline within the field of geotechnical engineering; namely environmental geotechnics, which is concerned with the application of geotechnical engineering to environmental control [1]. It is within this area that the concepts of stabilization, solidification, reuse and recycling of wastes in geotechnical engineering works are popularly encountered.

The process of stabilization and solidification of soil is meant to produce a new material that has different but improved engineering characteristics when compared with the parent constituents. Stabilization and solidification is meant to produce a hardened precipitate which binds and strengthens the soil mass, coats and incorporates some contaminant molecules in the siliceous solids and blocks channels between pores [2]. The production of the hardened precipitate referred to as solidification which can be achieved by cement, lime, fly ash and a combination of other additives is meant to achieve a level of immobilisation of whatever contaminants that may be found within the soil by making the entire soil matrix less soluble in water and in the end giving the soil a better geotechnical property.

Used oil on the other hand refers to any oil which has been refined from crude oil or any synthetic oil that has been used and as a result of such use is contaminated by physical or chemical impurities [3]. They constitute a significant part of crude oil related liquid pollutants that are generated and discarded into the Nigerian environment annually; and finding a cheap, efficient and environmentally safe application of used engine oil will inevitably reduce pollution.

In studying the characteristics of Kuwaiti sand at 4\% contamination with crude oil, Alsanad et al., [4] observed an increase in the soil California Bearing Ratio (CBR). A similar increase with crude oil was also reported by Otunyo [5] in Nigeria while working on a range of silty-clay and sandy-clay soils for which the CBR of contaminated soils were higher than the uncontaminated ones. With respect to used engine oil (UE0), some researchers such as [6 and 7] reported similar findings. The former found that for poorly graded sand (SP) contaminated with used engine oil (UEO), the soil unsoaked CBR increased from 0 to $6 \%$ contamination, but attaining a maximum increase at $3 \%$ contamination while the later observed the same

* Corresponding Author, Tel: +234-806-110-9704 
result for clayey gravel (GC) and clayey sand (SC) with maximum increase at $3 \%$ and $6 \%$ contamination respectively.

Ezeldin et al, [2], while working on heating oil and gasoline contaminated soils as a partial replacement for fine aggregates in concrete found that $60 \%$ of the uncontaminated concrete's compressive strength can be achieved at $40 \%$ Petroleum Contaminated Soil (PCS)/sand replacement while the leachability of benzene in the partially replaced concrete was not detectable after 24hours. Similarly 60\% PCS/sand replacement can be achieved in the production of concrete hollow blocks with compressive strength and density criteria being satisfied [8]. Furthermore, Hassan et al, [9] while considering the potential use of PCS in highway construction found that the Maximum Dry Density (MDD) and the Optimum Moisture Content (OMC) of the uncontaminated sample was higher than the contaminated sample mixed with cement in the range of $5-15 \%$. He concluded that $10 \%$ PCS partial replacement can be used as a base course and higher partial replacement percentages for the sub base while up to $40 \%$ partial replacement can be achieved in hot mix asphalt for medium to light weight traffic.

\section{SAMPLE COLLECTION AND PREPARATION}

The Laterite samples were collected from existing borrow sites. They are classified as clayey gravel (GC) and clayey sand (SC) according to the Unified Soil Classification System with the grading curves shown in Figure.1 and index properties in Table 1. They were contaminated with UEO at $3 \%$ contamination by weight of dry samples and allowed to age and equilibrate for three days according to US Army corps of Engineers' [10] recommendation. The contamination level of $3 \%$ was used because of its ability to increase CBR value; and also soils contaminated with up to $3 \%$ UEO is regarded as non hazardous by the New Jersey department of environmental pollution of the United States of America [6].

\section{EXPERIMENTAL TESTS}

All experimental tests were done in accordance with the recommendations of BS 1377 [11] and BS 1924 [12] and the tests include sieve analysis, Atterberg's limits, compaction test, specific gravity test, and the California Bearing Ratio (CBR) test. Specimens for the CBR test (soaked and unsoaked) were prepared at the optimum moisture content (OMC) and maximum dry density (MDD) using the CBR compaction mould. The samples for soaked CBR test were cured for six days and soaked for 24 hours before testing in line with Nigerian general specifications for roads and bridges [13]. The minerals present in the soil and their chemical composition were identified using the X-ray diffraction (XRD) and the X-ray fluorescence (XRF) tests; and shown in Tables 2 and 3 respectively.

\section{RESULTS}

The results of sieve analysis, Atterberg's limits test, Xray diffraction and X-ray fluorescence tests, compaction test and CBR tests are as shown in Figures 1 to 6 and Tables 1 to 3 .

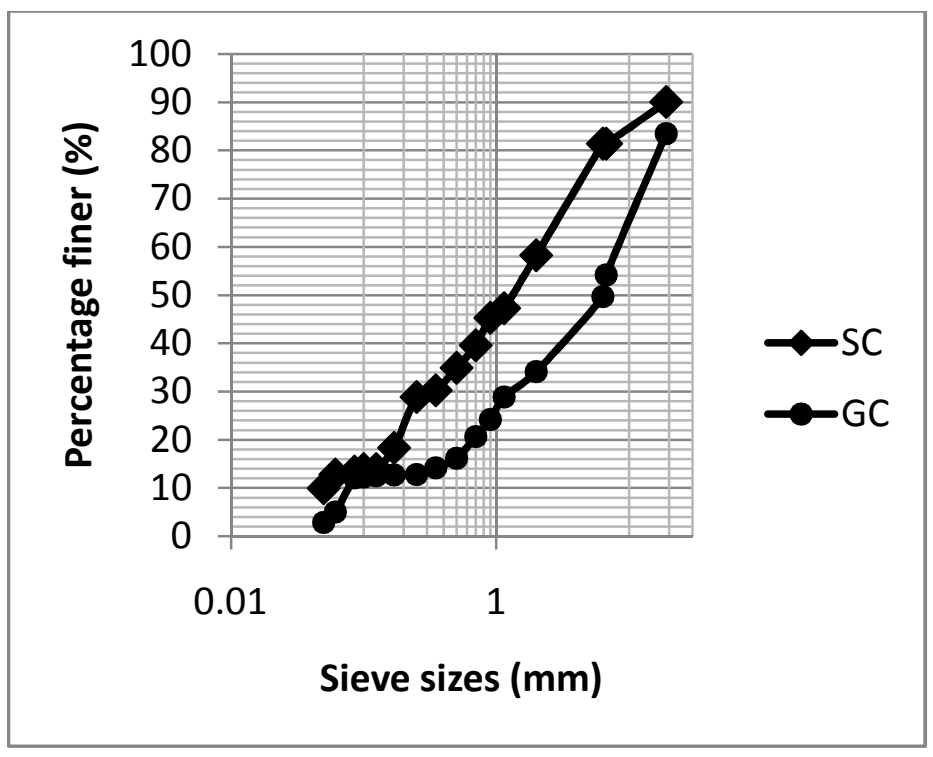

Figure 1: Sieve analysis of soil samples

Table 1: Summary of Index Properties

\begin{tabular}{lcccc}
\hline $\begin{array}{l}\text { Un-contaminated } \\
\text { Sample }\end{array}$ & LL & PL & PI & $\mathrm{G}_{\mathrm{s}}$ \\
\hline GC & 44.4 & 20.4 & 24 & 2.7 \\
SC & 34 & 18.5 & 15.5 & 2.8 \\
\hline
\end{tabular}

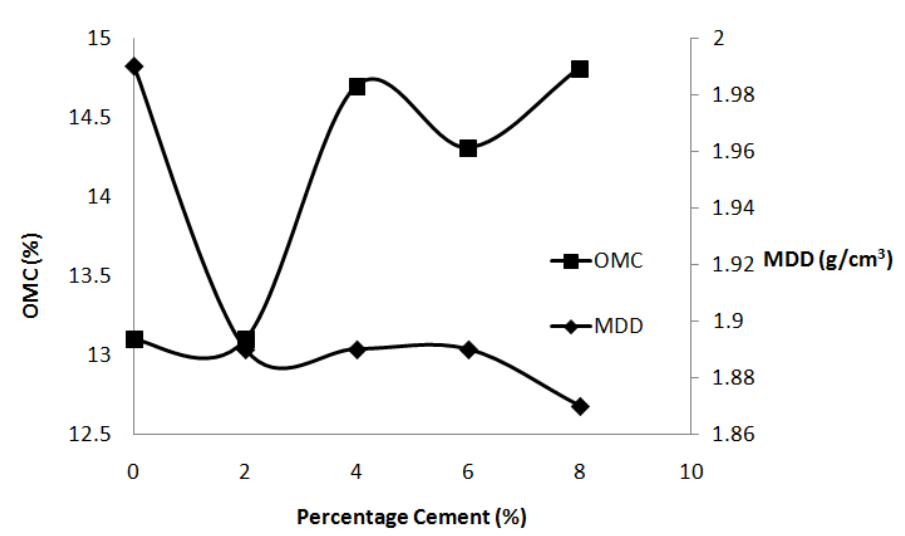

Figure 2: Variation of MDD and OMC with OPC for uncontaminated clayey Gravel (GC) 
Table 2: Chemical Composition of Soil Samples (X-Ray Fluorescence)

\begin{tabular}{ccc}
\hline & \multicolumn{2}{c}{ Concentration (\%) } \\
\cline { 2 - 3 } Chemical composition & $\begin{array}{c}\text { Clayey Sand } \\
\text { (SC) }\end{array}$ & $\begin{array}{c}\text { Clayey Gravel } \\
\text { (GC) }\end{array}$ \\
\hline $\mathrm{Al}_{2} \mathrm{O}_{3}$ & 24.00 & 27.5 \\
$\mathrm{SiO}_{2}$ & 45.90 & 46.8 \\
$\mathrm{~K}_{2} \mathrm{O}$ & 0.24 & 0.11 \\
$\mathrm{CaO}$ & 0.27 & 0.21 \\
$\mathrm{TiO}_{2}$ & 4.81 & 4.95 \\
$\mathrm{~V}_{2} \mathrm{O}_{5}$ & 0.18 & 0.19 \\
$\mathrm{CrO}_{3}$ & 0.033 & 0.023 \\
$\mathrm{MnO} \mathrm{Fe}_{2} \mathrm{O}_{3}$ & 0.041 & 0.022 \\
$\mathrm{Sc}_{2} \mathrm{O}_{3}$ & 20.73 & 20.20 \\
$\mathrm{Bi}_{2} \mathrm{O}_{3}$ & 0.003 & - \\
\hline
\end{tabular}

Table 3: Mineralogical Composition of Soil Samples ( $X$ Ray Diffraction Test)

\begin{tabular}{|c|c|}
\hline $\begin{array}{l}\text { Soil } \\
\text { Samples }\end{array}$ & Minerals \\
\hline SC & $\begin{array}{l}\text { Sillimanite, Kilchoanite, Wollastonite, } \\
\text { Tridymite }\end{array}$ \\
\hline GC & Rosenhahnite \\
\hline
\end{tabular}

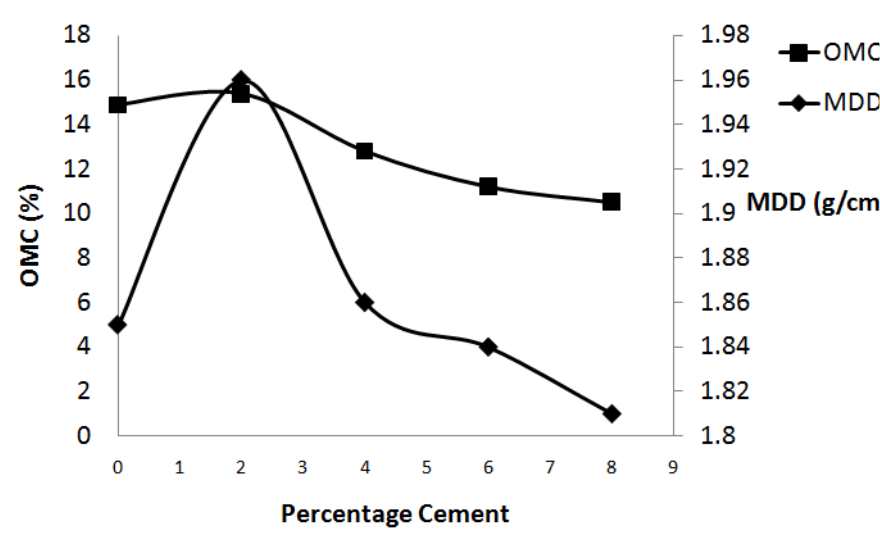

Figure 3: Variation of MDD and OMC with OPC for contaminated clayey Gravel (GC)

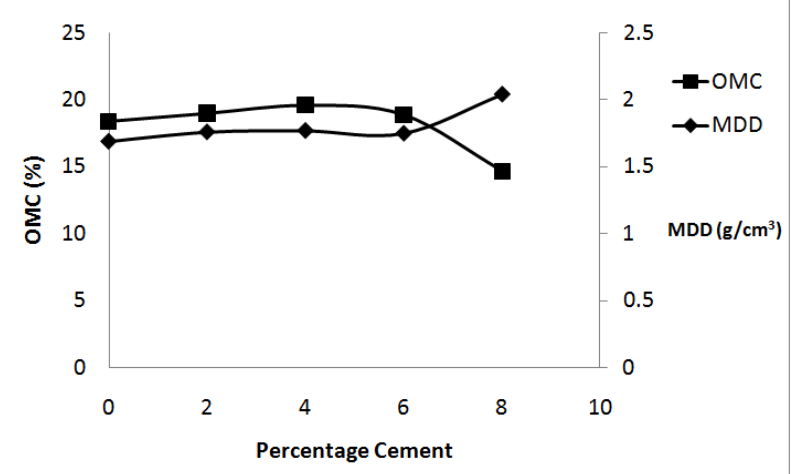

Figure 4: Variation of MDD and OMC with OPC for uncontaminated clayey Sand (SC)

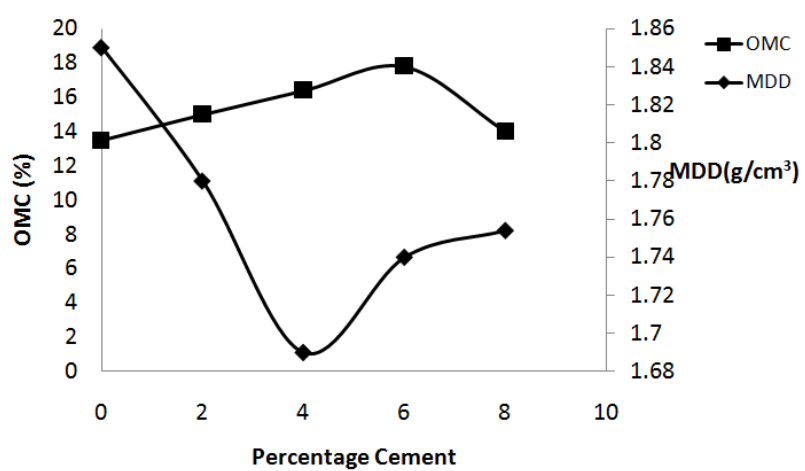

Fig. 5: Variation of MDD and OMC with OPC for contaminated clayey Sand (SC)

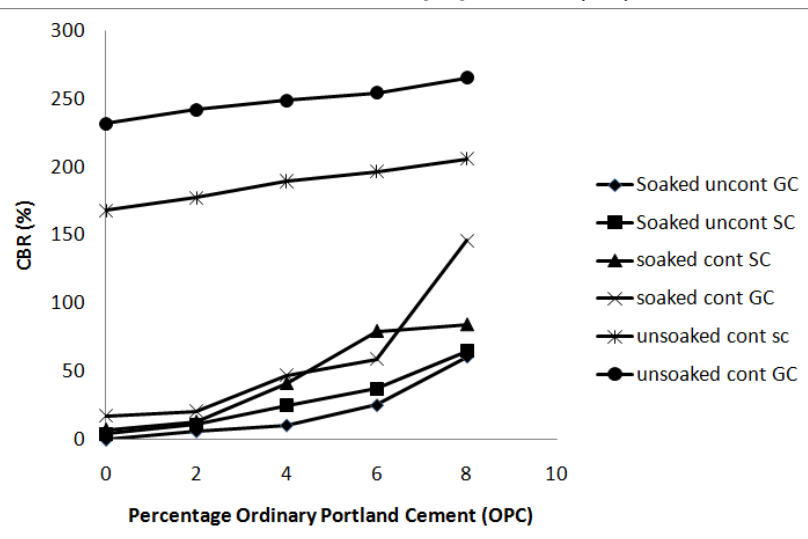

Fig.6: Variation of CBR with OPC for soaked and unsoaked samples

\section{DISCUSSION OF RESULTS}

\subsection{Index Properties and Soil classification}

The results of sieve analysis in Figure 1 shows that the uncontaminated soils contained at least $12 \%$ of fines while the plot of Plastic Limit (PL) and Liquid Limit (LL) was above the A-line. Comparing the above indices with the Unified Soil Classification (USC) chart, the soils can be classified as clayey gravel (GC) and clayey sand (SC). The mineralogical composition of the soils from Table 3 shows that they did not contain any problematic clay mineral.

\subsection{Compaction Test Results}

\subsubsection{Uncontaminated Clayey Gravel (GC)}

The MDD decreased with increasing cement content while the OMC increased with increasing cement as can be seen in Figure. 2. The increase in OMC can be attributed to the increase in Specific Surface Area (SSA) of the mix by the addition of the fine grain particles of Ordinary Portland Cement and the absorption of water by the OPC particles while the decrease in MDD according to Omotosho et al., [14] can be attributed to the fact that the primary hydration compounds catalyse and or supplement the natural micro-clustering potentials of the abundant 
sesquioxides in the Laterite and as a result the soil's natural fine grains are clustered together to form loosely bound and porous coarse grains resulting in decreased MDD.

\subsubsection{Contaminated Clayey Gravel (GC)}

Figure 3 shows that OMC decreased with increasing OPC addition while the MDD increased at 2\% OPC before decreasing. The increased MDD at 2\% OPC may be attributed to the fact that oil causes a lubrication of the soil grains resulting in a closer packing/densification of the clayey gravels with $2 \%$ OPC being the optimum amount of fines required to achieve the high densification. The reduction in OMC is attributed to the presence of oil in the soil.

\subsubsection{Uncontaminated Clayey Sand (SC)}

The variation of MDD and OMC with OPC content can be seen in Figure 4. The increase in MDD with cement content is attributed to the fact that OPC not only enhances the inter-cluster bonding strength but also fills the pore spaces of the soil with attendant reduction in pore volume thereby significantly increasing strength [15]. This resulted in an increase in OMC up to an optimum value before decreasing.

\subsubsection{Contaminated Clayey Sand (SC)}

The OMC of the contaminated sample showed a similar trend with the uncontaminated sample but was of a lower value of which is attributed to oil contamination while the MDD decreased to a minimum value before increasing. The decrease can be attributed to the fact that a given quantity of OPC is needed to overcome the negative effect of oil on the OPC after which an increase could be achieved as seen in Figure 5.

\subsection{California Bearing Ratio (CBR) Test Results}

Figure 6 shows that the uncontaminated samples had the least CBR values while the 3\% Used Engine Oil contaminated but unsoaked samples had the highest CBR value at 8\% OPC content respectively. Although the unsoaked samples had high values, they are not useful in design because of the lack of the effect of moisture which is not the case in actual construction. This therefore makes the contaminated but soaked samples the best in the category as they both met the requirement for use as a subbase material for heavy traffic as indicated by the Nigerian general specifications for roads and bridges [13].

\section{CONCLUSION}

It has been shown that a significant increase of $240.37 \%$ and $130.45 \%$ can be obtained in soaked California Bearing Ratio values of Used Engine Oil (3\%) -OPC (8\%) stabilized soils. Also of importance is the fact that chemical composition of 3\% Used Engine Oil contaminated soil is non hazardous to humans and the environment as corroborated by previous researchers [2, 6, and 8]. It is therefore possible to conclude that Used Engine Oil has a promising role in soil stabilization which serves as a means of improving the strength properties of a given soil and also a means of reducing the contamination of the environment with discarded use engine oil. Thus, Used Engine 0il at 3\% contamination may be referred to as an additive for soils where applicable.

\section{REFERENCES}

[1] Mitchel, J.K. and Filz, G.M. "The Role of Soil Mechanics in Environmental Geotechnics". Symposium on Recent Developments in Soil and Pavement Mechanics Rio de Janeiro, Brazil. A.A. Balkema, 1997, pp. 131-146.

[2] Ezeldin, H.S., Vaccari, D.A., Bradford, L., Dilcer, L., and Farouz, E. "Stabilization and Solidification of Hydrocarbon-contaminated Soils in Concrete". Journal of Soil contamination. Vol. 1 issue 1, 1992, pp. 61-72.

[3] U.S. EPA Solid Waste and Emergency Response $(5305 \mathrm{~W})$. "Managing Used Oil Advice for Small Businesses". EPA530-F-96-004 November 1996, p 1.

[4] Al-sanad, H.A., Eid., W.K and Isamel, N.F. "Geotechnical properties of oil contaminated Kuwaiti sand". Journal of Geotechnical Engineering, 121(5), 1995, pp. 407-412.

[5] Otunyo, A.W. "Reduction of the shear strength of soils in the Niger Delta area of Nigeria due to crude oil production". Nigerian Journal of Technology, Vol. 29 NO 2, 2010, pp. 130-140.

[6] Singh S.K., Srivastava, R.K., and John, S. "Studies on Soil contamination due to used motor oil and its remediation". Canadian Geotechnical Journal 46, 2009, pp. 1077-1083.

[7] Obeta, I.N and Eze-uzomaka, O.J. "Geotechnical Properties of Waste Engine Oil Contaminated Laterites". Nigerian Journal of Technology Vol. 32, No. 2, 2013, pp. 203-210.

[8] Hago A.W., Hassan, H.F., Al Rawas, A., and Al Hadidi, S. "Characterization of concrete blocks containing petroleum contaminated soils". Construction and Building materials Vol. 21, 2007, pp. 952-957.

[9] Hassan, H.F., Taha, R., Al Rawas, A., Al Shandoudi, B., Al Gheithi, K., and Al Barami A.M. "Potential uses of petroleum-contaminated soil in highway construction". Construction and Building Materials. Vol. 19, 2005, pp. 646-652. 
[10] U. S. Army Corps of Engineers. "Laboratory Soil Testing Engineering Manual". Washington, D. C., 2007.

[11] BS 1377. "Methods of testing Soils for Civil Engineering purposes". British Standards Institution, Her Majesty's stationery Office, London., 1995.

[12] BS 1924. "Methods of Testing for stabilized Soils". British Standards Institution, Her Majesty's stationery Office, London. 1990.

[13] Government of the federal republic of Nigeria. General Specifications (roads and bridges). Vol. II, pp. 145-157. 1997.
[14] Omotosho, 0 and Eze-Uzomaka O.J. "Optimal stabilisation of deltaic laterite". Journal of the South African Institution of Civil Engineering. Vol. 50 No 2, 2008, pp. 10-17.

[15] Horpibulsuk, S., Rachan, R., Chinkulkijniwat, A., Raksachon, Y., and Suddeepong, A. "Analysis of Strength Development in Cement-Stabilized Silty Clay based on Microstructural Considerations". Construction and Building Materials, Vol.24, 2010, pp.2011-2021. 